\title{
WEATHERIZING THE HOMES OF LOW-INCOME HOME ENERGY ASSISTANCE PROGRAM CLIENTS: A PROGRAMMATIC ASSESSMENT
}

Bruce Tonn

Richard Schmoyer

Sarah Wagner

OAK RIDGE NATIONAL LABORATORY 


\title{
DOCUMENT AVAILABILITY
}

Reports produced after January 1, 1996, are generally available free via the U.S. Department of Energy (DOE) Information Bridge.

Web site http://www.osti.gov/bridge

Reports produced before January 1, 1996, may be purchased by members of the public from the following source.

\author{
National Technical Information Service \\ 5285 Port Royal Road \\ Springfield, VA 22161 \\ Telephone 703-605-6000 (1-800-553-6847) \\ TDD 703-487-4639 \\ Fax 703-605-6900 \\ E-mail info@ntis.fedworld.gov \\ Web site http://www.ntis.gov/support/ordernowabout.htm
}

Reports are available to DOE employees, DOE contractors, Energy Technology Data Exchange (ETDE) representatives, and International Nuclear Information System (INIS) representatives from the following source.

Office of Scientific and Technical Information

P.O. Box 62

Oak Ridge, TN 37831

Telephone 865-576-8401

Fax 865-576-5728

E-mail reports@adonis.osti.gov

Web site http://www.osti.gov/contact.html

This report was prepared as an account of work sponsored by an agency of the United States Government. Neither the United States Government nor any agency thereof, nor any of their employees, makes any warranty, express or implied, or assumes any legal liability or responsibility for the accuracy, completeness, or usefulness of any information, apparatus, product, or process disclosed, or represents that its use would not infringe privately owned rights. Reference herein to any specific commercial product, process, or service by trade name,

trademark, manufacturer, or otherwise, does not necessarily constitute or imply its endorsement, recommendation, or favoring by the United States Government

or any agency thereof. The views and opinions of authors expressed herein do not necessarily state or reflect those of the United States Government or any agency thereof. 
ORNL/CON-486

WEATHERIZING THE HOMES OF LOW-INCOME HOME ENERGY ASSISTANCE PROGRAM CLIENTS:

A PROGRAMMATIC ASSESSMENT

Bruce Tonn, Richard Schmoyer

OAK RIDGE NATIONAL LABORATORY

Sarah Wagner

UNIVERSITY OF TENNESSEE, KNOXVILLE

Date Published: June 2002

Prepared for

U.S. Department of Energy

Office of Building Technology Assistance

Budget Activity Number EC 1701000

Prepared by

OAK RIDGE NATIONAL LABORATORY

Oak Ridge, Tennessee 37831

managed by

UT-BATTELLE, LLC

for the

U.S. DEPARTMENT OF ENERGY

under contract DE-AC05-00OR22725 



\section{CONTENTS}

EXECUTIVE SUMMARY

APPENDIX A RESIDENTIAL NATURAL GAS AND NO. 2 HEATING OIL PRICES AND

HEATING DEGREE DAYS.....................................................................

APPENDIX B CATEGORICAL REPEATED MEASURES GENERALIZED LINEAR

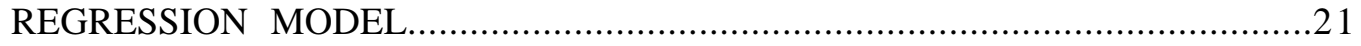

APPENDIX C STATE OF MASSACHUSETTS LIHEAP SCHEDULES ................................25 


\section{LIST OF FIGURES}

Figure $\quad$ Page

ES-1 Percentage of High Energy Benefit Recipients per Group Over Time.............................vii

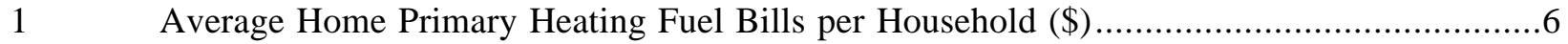

2 Percentage of High Energy Benefit Recipients per Group Over Time.............................7

3 Average LIHEAP Benefits Received per Household Over time......................................7

$4 \quad$ Number of Households in Sample Receiving LIHEAP Benefits Over Time ......................9

$5 \quad$ Differences Between Primary Heating Fuel Bills Incurred and

LIHEAP Benefits Customary ................................................................................ 11

6 Primary Heating Fuel Bills as a Percentage of Household Income

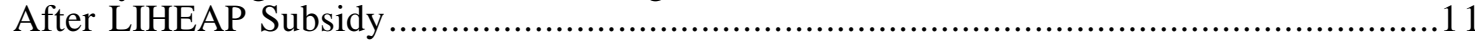




\section{LIST OF TABLES}

\section{Table}

Page

ES-1 Weatherization Dates and Dates of Expected Primary Heating Fuel

Usage and LIHEAP Benefit Impacts .... vii

1 Weatherization Dates and Dates of Expected Primary Heating Fuel Usage and LIHEAP Benefit Impacts

Demographics of Weatherization and Control Group Households (Averages) ...................6

3 Average Natural Gas and No. 2 Heating Oil Prices and

Total Heating Degree Days per Heating Season ...........................................................6

$4 \quad$ Average LIHEAP Benefits Received Hypotheses ..............................................

$5 \quad$ Characteristics of Household Leaving LIHEAP Program........................................... 10 


\section{EXECUTIVE SUMMARY}

The purpose of this project was to assess the relationships between two federal programs that support low income households, the Weatherization Assistance Program (WAP) and the Low Income Home Energy Assistance Program (LIHEAP). The specific question addressed by this research is: what impact does weatherizing homes of LIHEAP recipients have on the level of need for LIHEAP assistance? The a priori expectation is that the level of need will decrease. If this is the case, then it can be argued that a non-energy benefit of WAP is the reduction in the level of need for LIHEAP assistance for households receiving weatherization assistance.

The study area for this project was Boston, Massachusetts, which is representative of large northern urban areas. Additionally, Boston was chosen because one of its social service agencies, Action for Boston Community Development (ABCD), administers both WAP and LIHEAP programs. $\mathrm{ABCD}$ has a substantial client base of low-income households and was willing to cooperate in this study. In the State of Massachusetts, an income test is used to determine whether low-income households qualify for standard LIHEAP benefits. Benefits provided to eligible households are determined by a schedule that gauges benefit levels based on household income and number of members in the household. Additionally, households that consume large amounts of primary heating fuel can also qualify an additional high energy subsidy. It was expected that weatherization's biggest influence on the LIHEAP program would be in reducing the number of households qualifying for high energy subsidies.

Data were collected for three groups of households that received both weatherization and LIHEAP assistance and for one control group that only received LIHEAP assistance. Table ES-1 indicates the sample sizes, weatherization dates, and winter time periods when changes in energy consumption and receipt of LIHEAP benefits could be expected to be observed. The reason why there is a lag of one year when weatherization impacts upon LIHEAP benefits might be observed is that LIHEAP benefits - specifically high energy benefits-are based on the previous year's primary heat fuel bills.

Table ES-1. Weatherization Dates and Dates of Expected Primary Heating Fuel Usage and LIHEAP Benefit Impacts

\begin{tabular}{|l|c|c|c|c|}
\hline $\begin{array}{c}\text { Group } \\
\text { Number }\end{array}$ & Sample Size & Weatherization Date & $\begin{array}{c}\text { First Year of Primary } \\
\text { Heating Fuel Usage } \\
\text { Impact }\end{array}$ & $\begin{array}{c}\text { First Year of LIHEAP } \\
\text { Benefits Impact }\end{array}$ \\
\hline WX1 & 100 & Oct. 96-Sept. 97 & Winter 97/98 & Winter 98/99 \\
\hline WX2 & 100 & Oct. 97-Sept. 98 & Winter 98/99 & Winter 99/00 \\
\hline WX3 & 60 & Oct. 98-Sept. 99 & Winter 99/00 & Winter 00/01 \\
\hline CG & 100 & N/A & N/A & N/A \\
\hline
\end{tabular}

The demographic characteristics of the households in the three groups were similar for some variables and differed for others. The groups were similar in that the average age of head of household was high (over 50 years old), years in home was relatively high (the range was $12-15$ years), and percent of households headed by females was high (the range was $75-81 \%$ ). Each group had a higher percentage reporting natural gas as their primary heating fuel (the range was 80-90\%) than is reflected in the Boston area, which is around 60\%. Although all the average income levels were low, there was some variation in income amongst all four groups. There was also variation in average household size. Control group households were much more likely to live in multi-family dwellings and be Caucasian. 
As expected, the clearest impact of weatherization assistance on changes in LIHEAP assistance is shown in decreases in eligibility for high energy benefits post-weatherization. Figure ES-1 indicates that for two weatherization groups, WX1 and WX2, this is clearly the case. Requirements for high energy benefits also decreased for WX3, but this decrease appears one year earlier than anticipated.

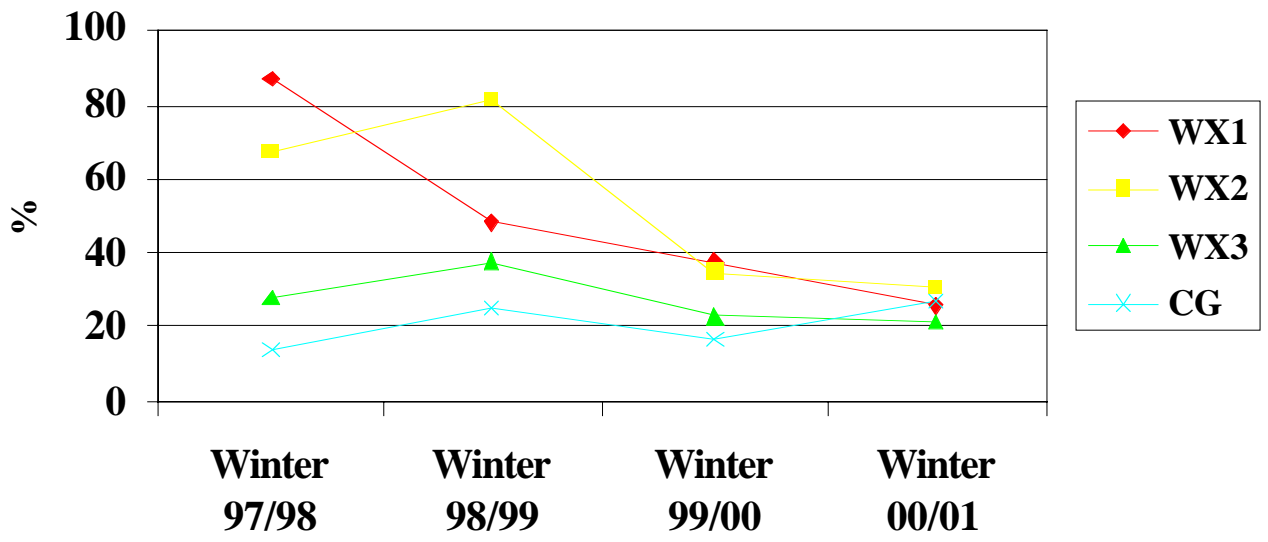

Time.

Figure ES-1. Percentage of High Energy Benefit Recipients per Group Over

A further statistical test also suggests that weatherization has a significant impact in reducing the overall needs for LIHEAP subsidies. However, it cannot be concluded that weatherization alone reduced the need for LIHEAP subsidies. Households in the sample that did drop out of the LIHEAP program had higher incomes, younger household heads, and fewer years in home than those who stayed in the program. These demographics suggest that households that dropped out of the program were more likely to experience income increases to make them ineligible for the program and were more likely to move out of the ABCD service area. Additionally, for no group for no time period did LIHEAP benefits cover all primary heating fuel bills. Thus, the overall conclusions of this study are that weatherization decreased the need for high energy benefits but did not lead to low income households relinquishing the need for standard LIHEAP benefits.

Additional research on the relationships between the WAP and LIHEAP programs could focus on a rural setting instead of an urban setting and could focus on states that administer their LIHEAP programs differently from the state of Massachusetts. With respect to the ABCD program, survey research could focus on why LIHEAP recipient households, both weatherized and nonweatherized, left the LIHEAP program and further data analysis could use actual primary heating fuel bills, which could then be weather adjusted. 


\section{INTRODUCTION}

The purpose of this project was to assess the relationships between two federal programs that support low-income households, the Weatherization Assistance Program (WAP) and the Low Income Home Energy Assistance Program (LIHEAP). The former is administered by the U.S. Department of Energy (DOE). The WAP Program "reduces the energy costs of low-income families - particularly the elderly, persons with disabilities, and children - by improving the energy efficiency of their homes and ensuring their health and safety." Any households at or below the higher of $150 \%$ of the federal poverty level or $60 \%$ of the state median income are federally eligible for this program. To date, approximately five million homes have been weatherized with a resulting average primary heating savings of $23 \%{ }^{1}$

LIHEAP is administered by the Department of Health and Human Services (HHS). Through this program, HHS provides funds to states to assist eligible households meet the costs of home energy. Like WAP, any households at or below the higher of $150 \%$ of the federal poverty level or $60 \%$ of the state median income are eligible for LIHEAP assistance. The state may not set the limit below $110 \%$ of the poverty level. Levels of assistance provided to each household are determined by each state. During the fiscal year 2000, states provided regular and crisis heating assistance benefits to approximately 4.1 million households. ${ }^{2}$

The specific question addressed by this research is: what impact does weatherizing homes of LIHEAP recipients have on the level of need for LIHEAP assistance? The hypothesis explored by this project is that the level of need will decrease. If this is the case, then it can be argued that a nonenergy benefit of WAP is the reduction in the level of need for LIHEAP assistance for households receiving weatherization assistance. We must point out that the number of recipients eligible for LIHEAP assistance may not decrease, because eligibility is not based on household energy use but only on household income. Additionally, the results of this research cannot be used to argue that increases in federal funds for weatherization assistance can be used to justify decreases in federal funds for LIHEAP because a case can be made that the current LIHEAP funding is insufficient to meet the needs of the nation's low income population. However, the results of this project may be used to argue that WAP provides a benefit to LIHEAP by lowering the amount of home heating assistance required by low-income households whose homes have been weatherized so that the overall level of assistance can be decreased for weatherization recipients. This could make more resources available for other households in need.

This project is one of many that have evaluated non-energy benefits attributable to low-income weatherization programs. It has been found that these programs benefit utilities and rate payers by reducing the probability the low income homes will be in arrears, have their service shut off, and require emergency gas service calls. Households benefit from increased property values, fewer fires, and improved comfort. Society benefits in several manners. Reduced energy consumption means, in most instances, less consumption of fossil fuels and, consequently, less emission of air and water pollutants. It has been found that weatherization programs generate local jobs. Reducing expenditures on energy helps to keep money in the community, thereby providing additional local economic benefits. For summaries of non-energy benefits attributable to weatherization programs, please consult Skumatz (2000), TecMRKT Works et al. (2001), Riggert et al. (1999) and Schweitzer and Tonn (2002).

${ }^{1}$ For more information about WAP, please visit

http://www.eren.doe.gov/buildings/weatherization_assistance/

${ }^{2}$ For more information about LHEAP, please visit http://www.acf.dhhs.gov/programs/liheap/ 
This is the first study that has assessed the WAP/LIHEAP relationship in a state that runs its LIHEAP program in a common way. This is one of the few studies that specifically assess income transfer benefits of WAP. One study of note by Brown et al. (1993) focused on reductions in the levels of need for unemployment benefits. Our study is unique in that it focused directly on WAP/LIHEAP interactions for a well-defined low income population over a several year period with the benefit of a control group. More details about the research design are presented next in Section 2.

Section 3 presents the results of this research. Section 4 provides concluding commentary. Appendix A provides detailed primary heating fuel price and heating degree day information. Appendix B presents the results of two statistical approaches developed to isolate the impacts of weatherization on levels of LIHEAP assistance received, taking into account important demographic variables. Appendix C contains the LIHEAP eligibility and benefits schedules used by the State of Massachusetts during the study period. 


\section{RESEARCH DESIGN}

This project employed a quasi-experimental research pre- and post-treatment design with random sampling and a control group to evaluate the potential impacts of WAP upon LIHEAP. In other words, the research design required a sample of households that received both weatherization assistance and LIHEAP assistance and a sample of households that only received LIHEAP assistance. To the extent possible, data on primary heating fuel use and LIHEAP benefits received were collected for several years prior to and following weatherization.

Because of time and resource constraints, it was decided that this study would focus on one area of the country. The study area chosen was Boston, Massachusetts, which is representative of large northern urban areas in the U.S. Even more specifically, we decided to focus on the area covered by one social service agency in the Boston area, Action for Boston Community Development (ABCD). Incorporated in 1962, ABCD is the largest human services agency in New England with a client base of over 100,000 low-income individuals and families. Among the numerous programs administered by $\mathrm{ABCD}$ are WAP and LIHEAP. ${ }^{3}$

$\mathrm{ABCD}$ staff were very supportive of this project and generous with their time. Access to WAP (non-computerized) and LIHEAP (computerized) program records were provided to this project. Before discussing the research design in detail, a few words about ABCD's LIHEAP and weatherization programs are required. $\mathrm{ABCD}$ has an obligation to assist all eligible households that apply for LIHEAP assistance. Each year, the State of Massachusetts develops a table that indicates the level of LIHEAP assistance to be provided to eligible households. For the 2000-2001 heating season, there were five income categories $(100 \%, 125 \%, 150 \%, 175 \%$, and $200 \%$ of poverty level) and thirteen household size categories (from 1 to 13 or more). A base LIHEAP benefit was defined for each household income category, with the benefit level declining as household income increases but increasing as household size increases. Additionally, for homes consuming higher levels of energy for home heating, an additional high energy benefit is provided. To determine which homes qualify for the high energy benefit, household primary heating fuel expenditures for the previous heating season are examined and those households whose expenditures exceed programmatic thresholds qualify. $\mathrm{ABCD}$ has an arrangement with local primary heating fuel suppliers to receive billing records of their LIHEAP clients. ABCD works with their client base to ensure that applications for LIHEAP assistance are up-dated each year. Appendix C contains the State of Massachusetts LIHEAP benefit schedules for the winters 1997/98 through 2000/01.

It should be noted that unlike the LIHEAP program, ABCD is not able to weatherize all eligible low income homes in any one year. In fact, ABCD only has funds to weatherize several hundred homes per year, which is only a fraction of ABCD's low income household client base. At the programmatic level, funds available for weatherization do not impact funds available for LIHEAP and visa versa. Also, there is no relationship between whether a home has been weatherized and whether the household can receive standard LIHEAP benefits because the latter are strictly income based.

The sample of households receiving both WAP and LIHEAP assistance was broken into three groups, WX1, WX2, and WX3. Shown in Table 1 are the time periods when each group received weatherization over a 3-year time span, from October 1996 to September 1999. Also shown are the dates when the impacts of weatherization on primary heating fuel use and level of LIHEAP benefits received should be observable. As expected, primary heating fuel savings should be observable in the first heating season after the weatherization period. LIHEAP benefits should be observable in the second heating season because in Massachusetts benefit levels are, in part, determined by previous years' household expenditures on energy for home heating, as described above.

\footnotetext{
${ }^{3}$ For more information about $\mathrm{ABCD}$, please visit http://www.bostonabcd.org/
} 
Table 1. Weatherization Dates and Dates of Expected Primary Heating Fuel Usage and LIHEAP Benefit Impacts

\begin{tabular}{|l|c|c|c|c|}
\hline $\begin{array}{c}\text { Group } \\
\text { Number }\end{array}$ & Sample Size & Weatherization Date & $\begin{array}{c}\text { First Year of Primary } \\
\text { Heating Fuel Usage } \\
\text { Impact }\end{array}$ & $\begin{array}{c}\text { First Year of LIHEAP } \\
\text { Benefits Impact }\end{array}$ \\
\hline WX1 & 100 & Oct. 96-Sept. 97 & Winter 97/98 & Winter 98/99 \\
\hline WX2 & 100 & Oct. 97-Sept. 98 & Winter 98/99 & Winter 99/00 \\
\hline WX3 & 60 & Oct. 98-Sept. 99 & Winter 99/00 & Winter 00/01 \\
\hline CG & 100 & N/A & N/A & N/A \\
\hline
\end{tabular}

The sample of weatherized homes was developed in the following fashion. First, a goal of 100 homes per group was set. This number is sufficient for statistical assessment and was consistent with the project's time and budget constraints. Second, a list of the names of all the heads of households that received weatherizations during each period was developed. Third, this list was cross-referenced against a much larger list of heads of households that received LIHEAP benefits during each period. All households that received high energy benefits were retained in the sample. Fourth, to reach the sample goal of 100 for WX1 and WX2, additional weatherization files were chosen at random. Homes that had received weatherization but not high energy benefits were included just in case a relationship between weatherization and reduction in standard LIHEAP benefits could be detected in the data. For example, it could be the case that the level of benefit from weatherization is enough to make the balance of the bill affordable to the household in some cases and therefore reduce LIHEAP program participation. This last step was not necessary for WX3 because records were only available for 60 weatherized homes. Information recorded for each household from the weatherization files included weatherization completion date, cost of weatherization work, high energy status (for each year in the study period), house type (i.e., single family or apartment) and home heating fuel type (i.e., fuel oil, natural gas).

The sample of control group homes was developed in the following fashion. An available paper-copy of the computerized LIHEAP database was consulted on site at ABCD. This printout contained in alphabetical order all computerized information about ABCD's LIHEAP client base. One household was chosen at random from each page from this multi-hundred page print-out. This list was then cross-checked against the list of all households that had received weatherization assistance from 1995 through 2000. Weatherization records were not conveniently available to conduct this cross-check earlier than 1995. Any household that had received weatherization in that time period was dropped and another name was chosen at random from the page. This process was repeated until 100 control group households were identified. We believe that this data limitation had little if any impact on our analysis because given the very large pool of LIHEAP recipients and the very small number of completed weatherizations prior to 1995 , it is improbable that many control group homes had been weatherized.

The following information about the 260 treatment group households and 100 control group households was then drawn from the LIHEAP print-out: ethnicity, age of household head, sex of household head, years in home, size of household, household income for each year in the 1997 to 2000 time period, LIHEAP benefits received each year during this time period (including eligibility for high energy benefits), and energy usage indicated on the clients' LIHEAP program applications for this time period. All the data collected were input into an ACCESS database and then imported into SAS for statistical analysis. 


\section{RESULTS}

Table 2 presents a summary of the demographic characteristics of the three weatherization groups and the control group. As expected, each group has a low average household income. Also similar across groups are the high average age of the household head (over fifty years old), high level of years in the home (the average was over ten years), and a very high rate of households headed by females, as compared to the general population. The high ages of the household heads, high level of years in the home, and very high rate of households headed by females were all unexpected results.

The groups differed in several respects. The average size of a control group household was smaller than the three weatherization groups but the size of the households over the weatherization groups varied, too. Control group households were much more likely to live in apartments and pay rent. A higher percentage of control group households are Caucasian whereas the weatherization group households were more likely to be African American. A higher percentage of WX1 and control group households reported natural gas as their primary home heating fuel than the other two weatherization groups. Overall, the percentage of homes heated with natural gas, between 80 to $90 \%$, is higher than the percentage of home in the greater Boston area, which is around $60 \%$.

Table 3 presents average residential prices for natural gas and fuel oil for the State of Massachusetts for five heating seasons, 96/97 to 00/01, and total heating degree days for this time period as recorded by a weather station in the city of Boston. (See Appendix A for more detailed, monthly data.) This additional background information is useful for interpreting descriptive statistics presented later in this section. Please note that the first two winters were cooler than the latter three winters. Natural gas prices were high in two winters, 98/99 and 00/01. Interestingly enough, fuel oil prices were very low in the winter of $98 / 99$ but high in 00/01. All else being equal, lower energy bills would be expected in warmer winters with lower energy prices, such as 98/99 and 99/00.

Figure 1 presents average home primary heating fuel bills for the three weatherization groups and the control group. These numbers represent total household home primary fuel heating bills - paid by the LIHEAP subsides and household contributions. Records with no energy bills during a period were dropped from the analysis. It should be noted that because the actual monthly billing records were not available to this project, it was not possible to weather-adjust energy consumption and energy expenditures.

Several observations can be made about the results presented in Figure 1 that indicate that weatherizations did lead to energy savings. First, households in the three weatherization groups had higher primary heating fuel bills pre-weatherization than the control group (see Winter 96/97). This result is expected because more of these homes are single family and because these homes were probably in more need of weatherization. Second, post-weatherization (i.e., by the Winter 99/00), the primary heating fuel bills for the treatment groups all decreased from the baseline (i.e., Winter 96/97) while control group bills increased, indicating that weatherization lead to decreases in primary heating energy demand the treatments homes.

Examining changes in bills from winter to winter also indicates that weatherized homes' primary heating fuel bills are relatively lower post-weatherization, as expected. For example, the percentage drop in bills for the first weatherization group, WX1, post-weatherization is $18.1 \%$ (from Winter 96/97 to Winter 97/98), which is larger than for the other two treatment groups (WX2 - 13.3\%, WX3 $-9.8 \%)$ and the control group $(9.5 \%)$ for that period of time. This same observation holds for the second weatherization group, WX2, which experienced a much larger drop in bills, $18.2 \%$, postweatherization (from Winter 97/98 to Winter 98/99) than the other two treatment groups (WX1-8.2\%, WX3 - 14.4\%) and the control group (3.0\%). The only case that is not as clear relates to the third weatherization group, WX3, where primary heating fuel bills decreased sharply, $14.4 \%$, the year prior to weatherization (from Winter 97/98 to Winter 98/99) but increased the year post-weatherization (from Winter 98/99 to Winter 99/00). However, given approximately the same weather conditions as the previous year, a nearly $50 \%$ increase in fuel oil prices (which increased bills for all the groups), and the fact that this group has a higher percentage of fuel oil users than the other groups, it could be expected that the bills for this group would have increased much more from Winter 98/99 to Winter 
Table 2. Demographics of Weatherization and Control Group Households (Averages)

\begin{tabular}{|l|c|c|c|c|}
\hline \multicolumn{1}{|c|}{ Variable } & WX1 & WX2 & WX3 & CG \\
\hline $\mathrm{N}$ & 100 & 100 & 60 & 100 \\
\hline Income 1997 & $\$ 10,441$ & $\$ 12,694$ & $\$ 12,724$ & $\$ 10,091$ \\
\hline Income 1998 & $\$ 11,504$ & $\$ 13,942$ & $\$ 14,090$ & $\$ 10,490$ \\
\hline Income 1999 & $\$ 12,080$ & $\$ 15,372$ & $\$ 15,456$ & $\$ 11,056$ \\
\hline Income 2000 & $\$ 13,874$ & $\$ 16,128$ & $\$ 15,810$ & $\$ 12,585$ \\
\hline Age Household Head & 54 & 53 & 52 & 58 \\
\hline Years in Home & 15 & 14 & 12 & 14 \\
\hline Household Size & 2.5 & 2.7 & 2.9 & 2.3 \\
\hline Home Ownership (\%) & & & & \\
\hline Single-family own & 29 & 44 & 35 & 11 \\
\hline Single-family rent & 2 & 4 & 0 & 5 \\
\hline Multi-family own & 10 & 8 & 8 & 9 \\
\hline Multi-family rent & 59 & 44 & 57 & 75 \\
\hline Fuel Type (\%) & & & & \\
\hline Gas & 90 & 82 & 80 & 89 \\
\hline Oil & 10 & 18 & 20 & 11 \\
\hline Sex of Household Head (\%) & & & & \\
\hline Male & 23 & 24 & 25 & 19 \\
\hline Female & 76 & 76 & 75 & 81 \\
\hline Ethnicity/Race & 30 & 32 & 40 & 56 \\
\hline Caucasian & 9 & 36 & 38 & 17 \\
\hline African American & & 18 & 3 & 12 \\
\hline Hispanic & & & 7 & 8 \\
\hline Chinese & & & & \\
\hline Pacific Islander & & & & \\
\hline Other & & & & \\
\hline
\end{tabular}

Table 3. Average Natural Gas and No. 2 Heating Oil Prices and Total Heating Degree Days per Heating Season

\begin{tabular}{|l|c|c|c|}
\hline Heating Season & $\begin{array}{c}\text { Natural Gas Price } \\
\left(\$ / \text { thousand } \mathrm{ft}^{3}\right)\end{array}$ & $\begin{array}{c}\text { No. 2 Heating Oil } \\
\text { Price } \\
(\$ / \text { gallon })\end{array}$ & $\begin{array}{c}\text { Heating Degree Days } \\
\text { (total) }\end{array}$ \\
\hline Winter 96/97 & 9.19 & 1.04 & 4355 \\
\hline Winter 97/98 & 9.27 & 0.89 & 4453 \\
\hline Winter 98/99 & 10.39 & 0.75 & 4185 \\
\hline Winter 99/00 & 8.76 & 1.12 & 4122 \\
\hline Winter 00/01 & 11.12 & 1.32 & 3590 \\
\hline
\end{tabular}




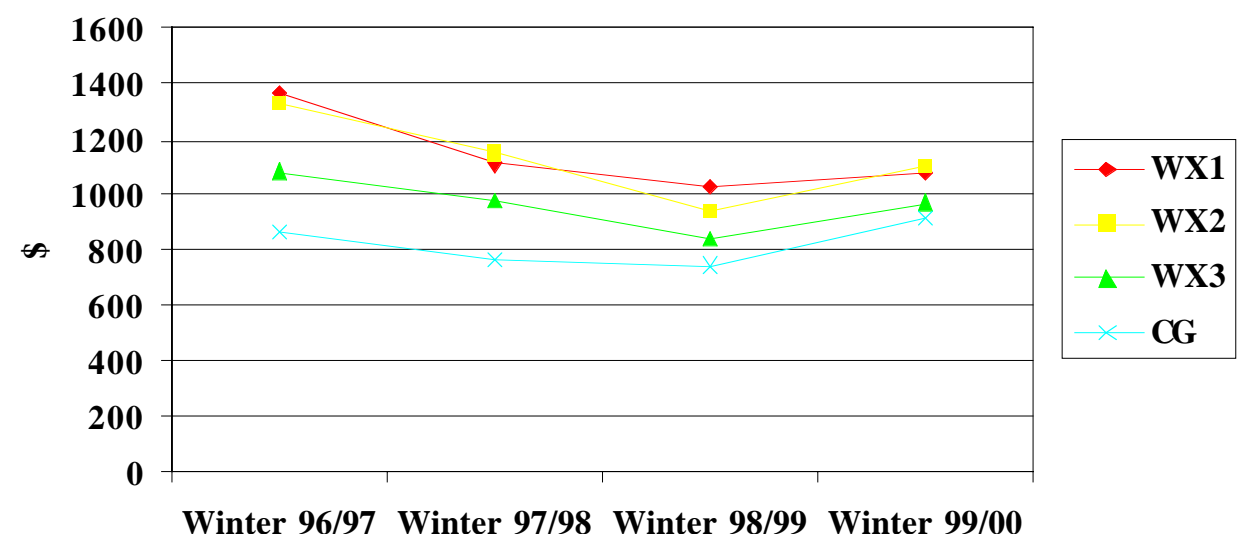

Figure 1. Average Home Primary Heating Fuel Bills per Household (\$).

99/00 than the other groups. That the average increase in primary heating fuel bills was lower for WX3 than increases experienced by two of the three groups is an indication of the positive impact of weatherization on the WX3 treatment group.

Figure 2 presents the percentage of high energy benefit recipients in each of the four groups for four heating seasons. Remember that the impacts of weatherization on the determination of high energy benefits is expected to lag one year because the high energy subsidy determination is based on the previous years' primary heating fuel bills. Thus, for example, for WX1, a substantial decrease in high energy benefit recipients is expected in winter 98/99. Indeed, this is the case, as the percentage of recipients dropped nearly one-half from the previous heating season. WX2 shows an even higher percentage drop, over fifty percent from winter 98/99 to winter 99/00. WX3 shows a significant drop, but as with primary heating fuel bills, appears to have taken place one year earlier than expected. By the post-weatherization period, winter 00/01, the percentages of high energy users in the three treatment groups are similar to the percentage of high energy users in the control group. Thus, these results strongly suggest that weatherization helped to reduce the need for high energy benefits. This effect could be expected to last for twenty years, which is the typical lifetime assumed for weatherization measures (Brown et al. 1993).

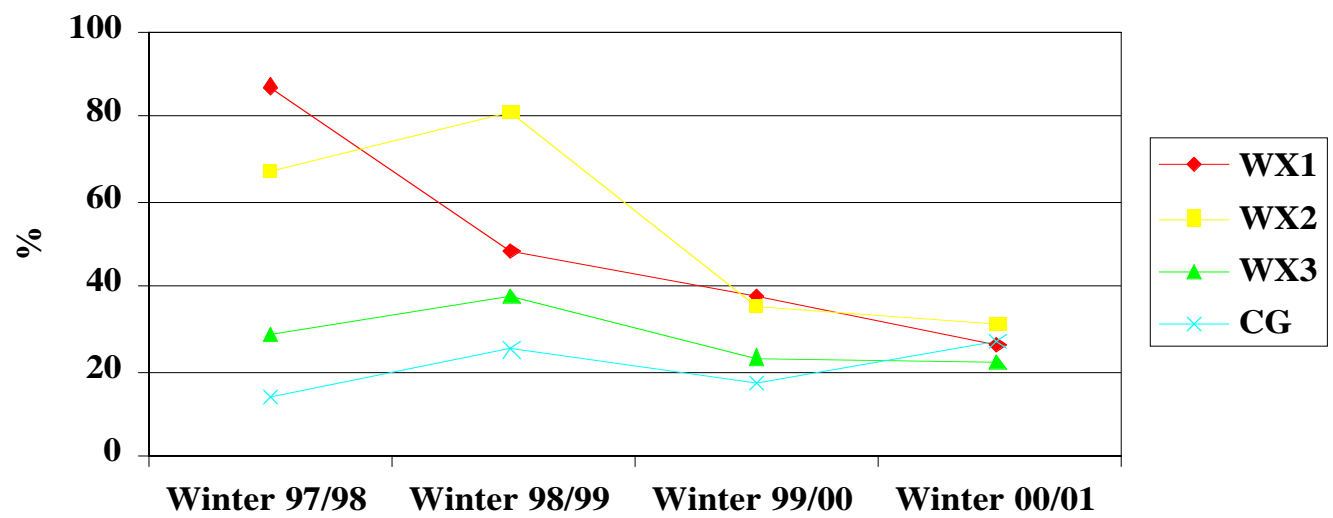

Figure 2. Percentage of High Energy Benefit Recipients per Group Over Time. 
Finding that the percentage of households receiving high energy benefits decreases postweatherization, a follow-on question is whether weatherization has an impact on the average LIHEAP benefits received by the treatment groups. Figure 3 presents the average LIHEAP benefits provided to households in each group. For these calculations, households not receiving benefits were treated as missing values for those periods when no benefits were received.

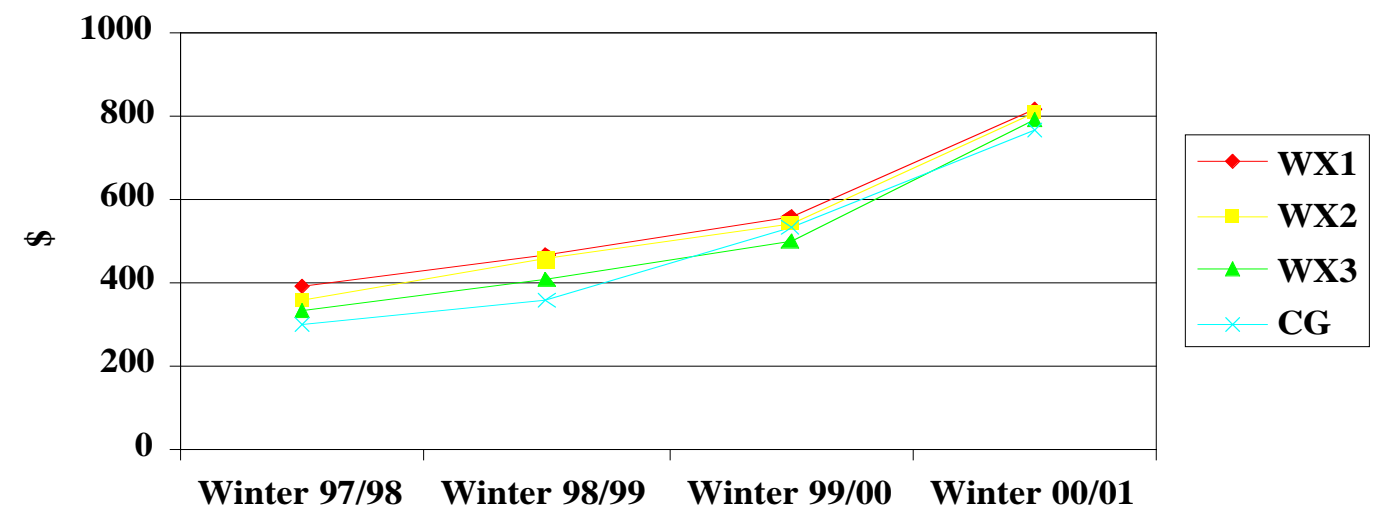

Figure 3. Average LIHEAP Benefits Received per Household Over Time.

One observation is that average benefit levels increased for all groups over time. This is because the availability of LIHEAP funds increased over time. Pertinent to this study, it was expected that treatment households' benefit levels post-weatherization would come to resemble the benefit levels of the control group or even drop below the levels of the control group because weatherization could reduce primary heating fuel bills to levels below that of the average LIHEAP recipients. It was also expected that benefit level changes for treatment groups post-weatherization would be more modest than pre-weatherization. With respect to the first expectation, it can be noted that in the Winter 97/98 winter, average benefits received by WX1, WX2 and WX3 were 130\%, 110\%, and 110\% of the control group benefits, respectively. By Winter 00/01, the percentages were 107\%, 105\%, and 103\%, much closer to the benefits received by the control group. The results in Figure 3 also tend to support the second expectation. Part of the problem is that the benefits received by the control group appear to vary considerably from period to period, which is reflected by the variation in number of control group households receiving high energy benefits from period to period (see Figure 2).

The results presented in Table 4 are somewhat more definitive. Unlike the previous analysis, for these calculations, households with no reported LIHEAP benefits were not treated as missing values but were re-coded as zero benefits. This was done under the assumption that households could have dropped out of the LIHEAP program, and stopped receiving benefits, due to their participation in the weatherization program, even though LIHEAP program participation was not tied to the energy efficiency of homes. Twelve expectations were developed involving average LIHEAP benefits received pre- and post-weatherization. It was expected that average LIHEAP benefits received per household would be greater for each weatherization group than for the control group each winter every year pre-weatherization and during the year of weatherization. These expectations are based on the assumption that more households in the weatherization groups qualified for higher energy benefits than the control groups primarily because their homes were less energy efficient. One year after the weatherization period, it was expected that average LIHEAP benefits received per household would be less for each weatherization group than for the control group each winter. These expectations are based on the assumption that weatherization group homes are now more energy efficient, on average, than the control group homes, meaning that weatherization group households would be less likely to require high energy benefits. It is also possible that some households dropped out of the LIHEAP program because their primary heating fuel bills became more affordable. As Table 4 indicates, expectations were met in 11 of the 12 instances. 
Table 4. Average LIHEAP Benefits Received Hypotheses

\begin{tabular}{|c|c|c|c|c|c|c|}
\hline $\begin{array}{l}\text { Expectation } \\
\text { Number }\end{array}$ & $\begin{array}{c}\text { WX Group } \\
\text { Average } \\
\text { LIHEAP } \\
\text { Benefits } \\
\text { Received per } \\
\text { Household } \\
\text { Will be ... }\end{array}$ & Operator & $\begin{array}{l}\text { Than Control } \\
\text { Group } \\
\text { Average } \\
\text { LIHEAP } \\
\text { Benefits } \\
\text { Received per } \\
\text { Household }\end{array}$ & $\begin{array}{l}\text { WX Group } \\
\text { Average } \\
\text { LIHEAP } \\
\text { Benefits } \\
\text { Received per } \\
\text { Household }\end{array}$ & $\begin{array}{c}\text { Control } \\
\text { Group } \\
\text { Average } \\
\text { LIHEAP } \\
\text { Benefits } \\
\text { Received per } \\
\text { Household }\end{array}$ & $\begin{array}{c}\text { Expected } \\
\text { Results? }\end{array}$ \\
\hline 1 & WX1 - 97/98 & $>$ & CG - 97/98 & $\$ 382$ & $\$ 286$ & $\mathrm{y}$ \\
\hline 2 & WX1 - 98/99 & $<$ & CG - 98/99 & $\$ 342$ & $\$ 345$ & $\mathrm{y}$ \\
\hline 3 & WX1- 99/00 & $<$ & CG - 99/00 & $\$ 360$ & $\$ 500$ & $\mathrm{y}$ \\
\hline 4 & WX1 - 00/01 & $<$ & CG- 00/01 & $\$ 435$ & $\$ 654$ & $\mathrm{y}$ \\
\hline 5 & WX2- 97/98 & $>$ & CG - 97/98 & $\$ 355$ & $\$ 286$ & $y$ \\
\hline 6 & WX2 - 98/99 & $>$ & CG - 98/99 & $\$ 423$ & $\$ 345$ & $\bar{y}$ \\
\hline 7 & $\overline{W X 2}-99 / 00$ & $<$ & CG - 99/00 & $\$ 397$ & $\$ 500$ & $\mathrm{y}$ \\
\hline 8 & $\mathrm{WX} 2-00 / 01$ & $<$ & $\mathrm{CG}-00 / 01$ & $\$ 517$ & $\$ 654$ & $y$ \\
\hline 9 & WX3 - 97/98 & $>$ & CG - 97/98 & $\$ 310$ & $\$ 286$ & $\mathrm{y}$ \\
\hline 10 & WX3 - 98/99 & $>$ & CG- 98/99 & $\$ 383$ & $\$ 345$ & $y$ \\
\hline 11 & WX3- 99/00 & $>$ & CG- 99/00 & $\$ 387$ & $\$ 500$ & $\mathrm{n}$ \\
\hline 12 & WX3 - 00/01 & $<$ & $\mathrm{CG}-00 / 01$ & $\$ 554$ & $\$ 654$ & $\mathrm{y}$ \\
\hline
\end{tabular}

It is possible that the results in Figure 3 and Table 4 are influenced by the fact that households receiving weatherization assistance were more likely to drop out of the LIHEAP program, as explained above, despite the independence of the LIHEAP eligibility from a home's energy efficiency. Figure 4 presents results that appear to support this hypothesis. Indeed, with respect to post-weatherization periods for groups WX1 and WX2, there were significant drops in the total number of households receiving LIHEAP benefits. Households in WX3 also dropped, although it again appears that the impacts upon WX3 take place one year before expected.

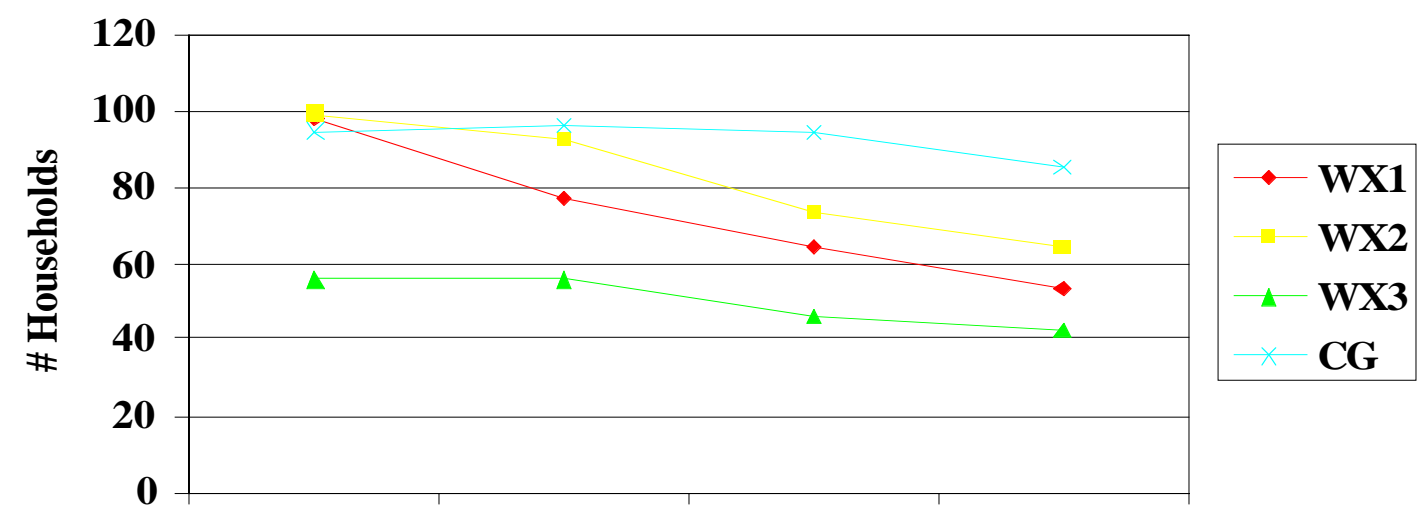

Winter 97/98 Winter 98/99 Winter 99/00 Winter 00/01

Figure 4. Number of Households in Sample Receiving LIHEAP Benefits Over Time. 
However, it cannot be strongly concluded from these results that weatherization assistance leads to households dropping out of the LIHEAP program altogether. First, the control group sample was chosen to ensure that each household received LIHEAP benefits for multiple years. Thus, it could be that non-weatherized households drop out at a higher rate than indicated by the control group indicated in Figure 4. Second, the results presented in Table 5 indicate that the households that left the LIHEAP program had higher incomes, fewer years in home, larger household sizes, and younger household heads than those households that remained in the program. Households with higher incomes to begin with are more likely than lower income households to increase their incomes enough to become ineligible for LIHEAP assistance. In addition, households with the demographics of those that dropped out of the program are likely to be more mobile than those that stayed in the program. Thus, the drop in the number of households receiving LIHEAP benefits in the treatment groups could be merely due to demographic factors.

Table 5. Characteristics of Households Leaving LIHEAP Program

\begin{tabular}{|l|c|c|c|c|c|c|c|c|c|}
\hline \multicolumn{1}{|c|}{ Group } & $\mathrm{N}$ & $\begin{array}{c}\text { Income } \\
1997\end{array}$ & $\begin{array}{c}\text { House- } \\
\text { hold } \\
\text { Size }\end{array}$ & $\begin{array}{c}\text { Years } \\
\text { in } \\
\text { Home }\end{array}$ & $\begin{array}{c}\text { Age } \\
\text { Head }\end{array}$ & $\begin{array}{c}\% \\
\text { Female } \\
\text { Head }\end{array}$ & $\begin{array}{c}\% \\
\text { Black }\end{array}$ & $\begin{array}{c}\% \\
\text { White }\end{array}$ & $\begin{array}{c}\% \\
\text { Hispanic }\end{array}$ \\
\hline WX1 & 49 & 11,460 & 3.0 & 14.5 & 48 & 76 & 33 & 35 & 16 \\
\hline WX2 & 41 & 12,621 & 2.7 & 12.4 & 52 & 78 & 34 & 32 & 22 \\
\hline WX3 & 23 & 13,297 & 3.1 & 6.9 & 42 & 78 & 52 & 26 & 9 \\
\hline CG & 22 & 13,386 & 2.8 & 8.3 & 60 & 95 & 18 & 45 & 14 \\
\hline $\begin{array}{l}\text { All HHDs } \\
\text { that left } \\
\text { program }\end{array}$ & 135 & 12,411 & 2.9 & 11.6 & 49 & 80 & 34 & 34 & 16 \\
\hline $\begin{array}{l}\text { All That } \\
\text { Remained }\end{array}$ & 226 & 10,729 & 2.3 & 15.1 & 58 & 76 & 29 & 42 & 11 \\
\hline
\end{tabular}

It also needs to be indicated that LIHEAP benefits do not cover all of a low income household's primary heating fuel bills in the State of Massachusetts in the years encompassed by this study (which is typical for LIHEAP programs around the country). As indicated in Figure 5, for each heating season participating households' primary heating fuel bills were hundreds of dollars more than the benefits received. The only pattern recognizable with respect to weatherization is that postweatherization, winter 99/00, the difference in bills and LIHEAP benefits received appears much smaller and is more comparable to the control group than pre-weatherization, especially for the winter of 97/98. Additionally, the percentage of household income devoted to primary heating fuel payments by low-income households, see Figure 6, is generally higher than the $3 \%$ devoted to all energy payments by non-low-income households as reported by DOE. Thus, these results suggest that weatherization does not lead households to drop out of the LIHEAP program entirely, as homes leaving the program are prone to be more mobile, and homes staying in the program are still poor and face primary heating fuel bills beyond their resources, even with LIHEAP subsidies.

Up to this point, the results strongly suggest that weatherization assistance reduces the need for high energy benefits but are ambiguous as to whether overall levels of LIHEAP assistance are also reduced. What is needed now are statistical tests to indicate whether LIHEAP assistance is reduced post-weatherization. Appendix B documents two approaches to this task: simple correlation and multiple regression. With respect to the former, a categorical variable was developed to indicate the level of LIHEAP assistance a household may have received in a year (e.g., no assistance, only standard benefits, high energy benefits). This variable is significantly correlated with weatherization with the expected sign. 


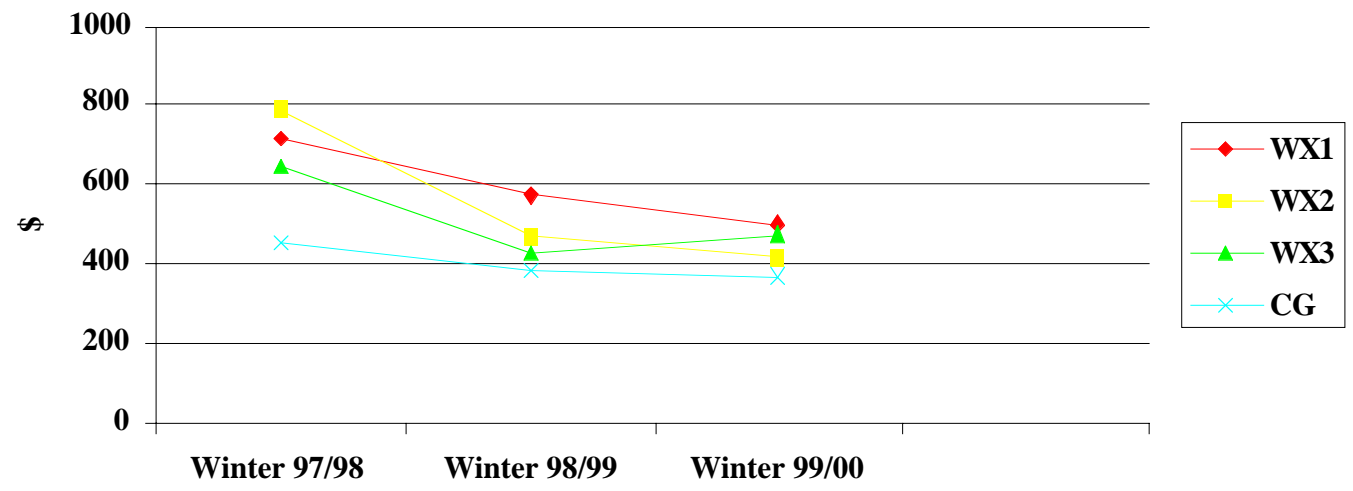

Figure 5. Difference Between Primary Heating Fuel Bills Incurred and LIHEAP Benefits Customary.

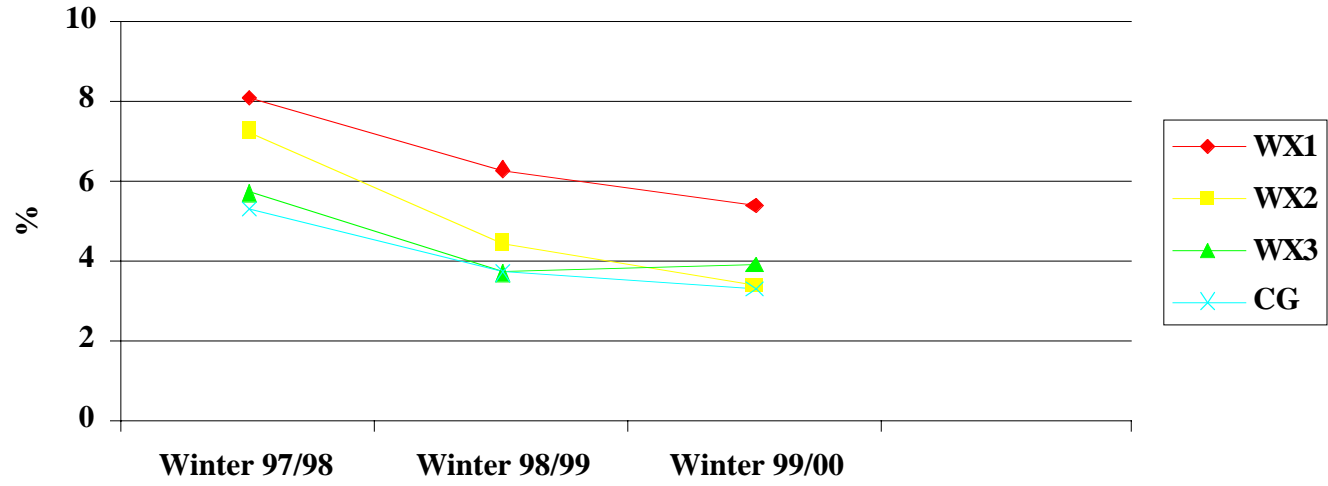

Figure 6. Primary Heating Fuel Bills as a Percentage of Household Income After LIHEAP Subsidy.

With respect to the latter, the categorical variable was used as the dependent variable in a categorical repeated measures generalized linear regression model. In this model, the weatherization variable coefficient was significant and had the expected sign, thus supporting our hypothesis that weatherization can be linked to reductions in needs for LIHEAP benefits. The significance of the coefficients for other independent variables in the model indicate that: households that are less likely to move and have more stable low income patterns (which might be the case for households with older heads than with younger heads) will receive a more stable pattern of LIHEAP subsidies over time; and smaller households (those headed by females) are less likely to require high-energy subsidies. 


\section{CONCLUSIONS}

This project assessed the relationships between two important federal programs aimed at assisting low income households, LIHEAP and WAP. Data were collected about low income households in Boston, Massachusetts and their receipt of LIHEAP and/or weatherization assistance. The overall conclusions of this study are that weatherization decreased the need for high energy benefits but did not lead to low income households relinquishing the need for standard LIHEAP benefits. Although these results are not unexpected, this is the first study to quantitatively address this question. What was unexpected were the profiles of the treatment groups and control group, which had much older household heads who had resided much longer in their homes than expected. The very high percentage of female headed households was also unexpected.

It was not possible to estimate a monetary benefit of the weatherization program to the LIHEAP program for a couple of reasons. First, the level of LIHEAP benefits changes each year, depending on funding from the U.S. Congress and the State of Massachusetts and expected energy prices. Thus, it was not possible to develop a baseline LIHEAP benefit. Second, it can be argued that the benefit of the weatherization program to LIHEAP is not a reduction in the number of households eligible for LIHEAP (because LIHEAP eligibility is solely based on income) but is actually related to how high-energy benefit funds could have been re-allocated to increase the average LIHEAP benefit per household over the entire program. Data were not available to this project to assess potential reallocations of LIHEAP funds.

Additional research on the relationships between the WAP and LIHEAP programs could focus on a rural setting instead of an urban setting and could focus on states that administer their LIHEAP programs different from the state of Massachusetts. With respect to the ABCD program, survey research could focus on why LIHEAP recipient households, both weatherized and nonweatherized, left the LIHEAP program and further data analysis could use actual primary heating fuel bills, pre- and post-weatherization, which could then be weather adjusted. Lastly, consideration should be given to refining specifications for treatment and control groups to improve comparability. For example, a future study could focus only on single family homes whose primary heating fuel was natural gas. 


\section{ACKNOWLEDGMENTS}

We wish to thank John Wells and his staff at ABCD for their valuable assistance in reviewing the study design for this project, providing us with access to the weatherization and LIHEAP data, and helping to interpret the results. We wish to thank Joel Eisenberg and Martin Schweitzer for their assistance in developing this project, interpreting the results and reviewing the draft report. We also thank Linda Berry, John Wells, and Gail McKinley for reviewing the draft report. We also wish to thank Rick Goeltz for providing assistance in acquiring the HDD data. 


\section{REFERENCES}

Brown, M., L. Berry, R. Balzer, and E. Faby. 1993. National Impacts of the Weatherization Assistance Program in Single-Family and Small Multifamily Dwellings. ORNL/CON-326, Oak Ridge National Laboratory, Oak Ridge, Tenn., May.

Liang, K. Y., and S. L. Zeger. 1986. "Longitudinal Data Analysis Using Generalized Models." Biometrica 73, 13-22.

LIHEAP Clearinghouse, 2002. Targeting LIHEAP Benefits: State Strategies Based on Household Income, Energy Burden and Heating Costs, February.

Riggert et al. 1999. An Evaluation of the Energy and Non-Energy Impacts of Vermont's Weatherization Assistance Program. TecMRKT Works, Oregon, WI., November.

Schweitzer, M., and B. Tonn. 2002. Non-Energy Benefits from the Weatherization Assistance Program: A Summary of Findings from the Recent Literature. ORNL/CON-484, Oak Ridge National Laboratory, Oak Ridge, Tenn., April.

Skumatz, L. 2000. Non-Energy Benefits Analysis for Selected PG\&E Residential Programs. Skumatz Economic Research Associates, Inc., Seattle, Wash., February.

TecMRKT Works, SERA, Inc., and Megdal Associates. 2001. Low Income Public Purpose Test (LIPPT) $3^{\text {rd }}$ Technical Memorandum, Draft. 


\section{APPENDIX A: RESIDENTIAL NATURAL GAS AND NO. 2 HEATING OIL PRICES AND HEATING DEGREE DAYS}

This table contains average monthly residential natural gas and fuel oil prices for the State of Massachusetts and total heating degree days as measured at a weather station in Boston for the five winters included in this study.

\begin{tabular}{|c|c|c|c|}
\hline Date & $\begin{array}{c}\text { Natural Gas } \\
\left(\$ / \text { thousand } \mathrm{ft}^{3}\right)^{*}\end{array}$ & $\begin{array}{l}\text { No. } 2 \text { Heating Oil } \\
\text { (\$/gallon)* }\end{array}$ & Heating Degree Days \\
\hline Oct. 1996 & 7.54 & 1.03 & 358 \\
\hline Nov. 1996 & 9.52 & 1.04 & 739 \\
\hline Dec. 1996 & 9.53 & 1.06 & 793 \\
\hline Jan. 1997 & 9.37 & 1.07 & 792 \\
\hline Feb. 1997 & 9.54 & 1.03 & 806 \\
\hline Mar 1997 & 9.62 & .98 & 868 \\
\hline Oct. 1997 & 8.51 & .90 & 383 \\
\hline Nov. 1997 & 9.7 & .91 & 693 \\
\hline Dec. 1997 & 9.94 & .90 & 860 \\
\hline Jan. 1998 & 9.08 & .89 & 955 \\
\hline Feb. 1998 & 9.12 & .88 & 826 \\
\hline Mar 1998 & 9.24 & .87 & 736 \\
\hline Oct. 1998 & 9.44 & .75 & 321 \\
\hline Nov. 1998 & 9.66 & .75 & 606 \\
\hline Dec. 1998 & 9.67 & .74 & 798 \\
\hline Jan. 1999 & 12.63 & .76 & 798 \\
\hline Feb. 1999 & 12.5 & .76 & 872 \\
\hline Mar 1999 & 8.46 & .76 & 790 \\
\hline Oct. 1999 & 8.15 & .91 & 363 \\
\hline Nov. 1999 & 8.92 & .97 & 505 \\
\hline Dec. 1999 & 8.32 & 1.00 & 851 \\
\hline Jan. 2000 & 8.91 & 1.24 & 851 \\
\hline Feb. 2000 & 8.86 & 1.40 & 887 \\
\hline Mar 2000 & 9.41 & 1.17 & 665 \\
\hline Oct. 2000 & 10.89 & 1.32 & 341 \\
\hline Nov. 2000 & 11.14 & 1.35 & 628 \\
\hline Dec. 2000 & 11.52 & 1.37 & 628 \\
\hline Jan. 2001 & 10.94 & 1.33 & 628 \\
\hline Feb. 2001 & NA & 1.30 & 925 \\
\hline Mar 2001 & $\overline{\mathrm{NA}}$ & 1.26 & 440 \\
\hline
\end{tabular}

* Source: Energy Information Administration 


\section{APPENDIX B: SIMPLE CORRELATION AND CATEGORICAL REPEATED MEASURES GENERALIZED LINEAR REGRESSION MODEL}

This appendix documents two approaches exploring a statistical relationship between weatherization and LIHEAP benefits: simple correlation and multiple regression. With respect simple correlation, a partially-ordinal variable was created to describe a household's level of benefits received for each year. The values are as follows:

5 = eligible for high energy benefits and used all benefits

4 = eligible for high energy benefits and did not use all benefits (i.e., primary heating fuel bills were less than the benefits for which the household was eligible to receive)

3 = eligible for standard benefits and used all benefits

2 = eligible for standard benefits and did not use all benefits

$1=$ did not receive benefits

It is expected, for instance, that a household receiving high energy benefits and weatherization assistance would move from category 5 to 3 or lower in the year following weatherization, resulting in a -2 or more change in this variable. It is expected that a household receiving standard benefits and weatherization assistance could move from category 3 to 2 or lower, resulting in a -1 or more change in this variable. It is not expected that households receiving weatherization assistance would move up the LIHEAP assistance scale. Furthermore, it is expected that households not receiving weatherization assistance would probably not systematically move up or down the LIHEAP assistance scale but could move up or down the scale with equal likelihood.

With these expectations in mind, the hypothesis tested was whether the weatherized group average change in the LIHEAP benefits scale minus the average change in the LIHEAP benefits scale of the control group was negative and significantly different from zero. Because the scale here is only partially ordinal, value differences were adjusted, rather than used directly. In addition to tied values (no change), changes from 4 to 2 and vise versa or 4 to 3 and vice versa were scored as 0 change, because a value of 4 could actually represent either a better or worse case than a 2 or a 3 . Other changes were scored as plus or minus 1 (depending on the direction of the change), except for changes from 1 to 5 or 5 to 1 , which were scored as a plus or minus 4 . Using this scoring system, the average difference was calculated to be -0.34 . A Z-test to determine whether this difference was different from zero produced a $\mathrm{z}$-score of -2.53 , which is significant at the .006 level. Thus, it can be concluded that weatherization is significantly correlated with lower LIHEAP benefit subsidies overall.

Lastly, we developed a statistical model that relates LIHEAP benefits received to weatherization controlling for demographic variables. In other words, the model explores the impact of the treatment, weatherization, on the outcome under study, receipt of LIHEAP benefits. As reported above, the results indicate that weatherization reduced the probability that households living in weatherized homes would require high energy benefits. It is also reported that weatherization appears to be correlated to reduced LIHEAP benefits when one employs a partially-ordinal scale to measure LIHEAP benefits. However, these observations do not control for demographic influences upon receipt of LIHEAP benefits. For example, might sex or age of the household head have more on impact LIHEAP benefits received than the weatherization treatment? The model described below attempts to sort out answers to these types of questions.

The model developed herein is more complicated and the statistical technique used more sophisticated than normally found in these types of analyses. There are two reasons for this. First, the dependent variable is categorical, produced given the methodology described above for the correlation test. Because the model used in the analysis below requires an ordinal dependent variable, and because very few households fell into categories 2 or 4 , homes that fell into categories 2 or 4 were re-coded into category 3 . The resulting three-level categorical variable is ordinal. Because of the categorical nature of the dependent variable, standard linear regression techniques, which assume continuous dependent variables, could not be used. 
The second complexity of this model relates to its observations. Up to three pre-weatherization observations were defined for each household in the study, for the winters 1997/98, 1998/99, and 1999/00. For WX1, 1997/98 was recorded as a pre-treatment year and the years 1998/99 and 1999/00 were recorded as post-treatment years. Each control group record was recorded as pre-treatment and coded as weatherization $=0$. For WX2,1998/99 was recorded as a pretreatment year and1999/00 was recorded as a post-treatment year (i.e., as weatherization $=1$ ). For example, for each household in WX3, there is one record pre-weatherization, 1997/98. The winter of 99/00 was recorded as a pre-treatment year because LIHEAP benefits were not expected until the following winter.

This approach to developing the observations for the model incorporates repeated measures-i.e., more than one observation per household. To estimate this model, a procedure in SAS was used to estimate a categorical repeated measures generalized linear regression model (Liang and Zeger 1986). The results are presented in Table B.1.

Table B.1. Results of Categorical Repeated Measures Generalized Linear Regression Model: Dependent Variable - LIHEAP Benefits Received

\begin{tabular}{|l|c|c|c|c|}
\hline \multicolumn{1}{|c|}{ Variable } & Coefficient & Standard Error & Z Score & $\begin{array}{c}\text { Significance } \\
\text { Level }\end{array}$ \\
\hline Intercept 1 & -0.50 & 0.38 & -1.31 & .19 \\
\hline Intercept 2 & 1.73 & 0.37 & 4.61 & .0001 \\
\hline Weatherization (if No) & -0.48 & 0.21 & -2.23 & .026 \\
\hline Year97 & -0.97 & 0.18 & -5.54 & .0001 \\
\hline Year98 & -0.71 & 0.14 & -5.09 & .0001 \\
\hline Years in Home & -0.02 & 0.01 & -2.28 & \\
\hline Age of HHD Head & -0.01 & 0.01 & -2.04 & .0418 \\
\hline Sex of HHD (if female) & 0.45 & 0.21 & 2.16 & .0306 \\
\hline African American & -0.24 & 0.25 & -.95 & .34 \\
\hline Caucasian & 0.18 & 0.25 & 0.74 & .46 \\
\hline Chinese & 0.05 & 0.33 & 0.15 & .88 \\
\hline
\end{tabular}

Before interpreting the results in Table B.1, a few other points need to be made. First, several demographic variables that appear in Table 2 have been dropped. These include household size, home ownership and household income. The first two were dropped because they were insignificant and correlated with a remaining variable, sex of the household head. Income was dropped because it was not collected in years when households did not receive benefits, which resulted in a large number of additional observations that were dropped from the model, including all households falling into category 1 .

Second, the non-linear statistical technique employed to estimate this model is based on cumulative logits. Because the dependent variable has three scales, there are two cumulative logits, $\log$ $[\mathrm{p} 1 /(1-\mathrm{p} 1)]$ and $\log [(\mathrm{p} 1+\mathrm{p} 2) / \mathrm{p} 3]$, where $\mathrm{p} 1=\mathrm{P}($ LIHEAP Class $=1), \mathrm{p} 2=\mathrm{P}($ LIHEAP Class $=3)$, and p3 $=\mathrm{P}($ LIHEAP Class $=5)$. This explains why there are two intercepts in the model. Also, with the cumulative logits and LIHEAP classes defined as above, a positive coefficient for years in home (or any variable) denotes that the cumulative logits tend to increase, and the LIHEAP classes tend to decrease with increasing years in home (or any other variable). In other words, interpretation of the signs of the coefficients is opposite how coefficients are interpreted in standard multiple regression models. 
With these thoughts in mind, let's review the weatherization variable coefficient (see Table B.1). The coefficient is negative when the home is NOT weatherized. This means that the cumulative logits tend to decrease and the LIHEAP classes tend to increase, toward the receiving high energy benefits end of the categorical scale. This is as expected. Additionally, the variable is quite significant. Thus, the model supports the basic thesis of this study, that weatherization can lead to reduced levels of LIHEAP subsidies.

The model also has several other significant variables. Two dummy variables, added to help control for aspects that might make one year's LIHEAP benefits different from other years, Year97 and Year98 were both significant. Three demographic variables were also significant. Years in home and age of household head were significant and carry negative signs on their coefficients. This implies that as these variables increase, the class of LIHEAP benefits increases. The opposite is the case for households headed by females, where the class of LIHEAP benefits decreases. These results can interpreted to mean that households that are less likely to move and have more stable low income patterns (which might be the case for households with older heads than with younger heads) will receive a more stable pattern of LIHEAP subsidies over time. Additionally, smaller households, those headed by females, are less likely to require high energy subsidies, which are based strictly on previous winter's energy bills and not on household size. 
APPENDIX C

STATE OF MASSACHUSETTS LIHEAP SCHEDULES 


\section{FUEL ASSISTANCE PROGRAM 2000-2001 ELIGIBILITY GUIDELINES}

MASSACHUSETTS FY2001 LIHEAP INCOME ELIGIBILITY CHART

ABCD FUEL ASSISTANCE PROGRAM ELIGIBILITY IS BASED ON TOTAL GROSS INCOME (BEFORE TAXES \& DEDUCTIONS) FOR ALL HOUSEHOLD MEMBERS AND VULNERABILITY TO ENERGY COSTS.

***CALL 357-6012 FOR ABCD FUEL ASSISTANCE PROGRAM $* * *$

Rev. \#5, 2/21/2001

\begin{tabular}{|c|c|c|c|c|c|}
\hline $\begin{array}{l}\text { Number in } \\
\text { Household }\end{array}$ & $100 \%$ of Poverty & $125 \%$ of Poverty & $150 \%$ of Poverty & $\begin{array}{l}175 \% \text { of } \\
\text { Poverty }\end{array}$ & $\begin{array}{l}200 \% \text { of } \\
\text { Poverty }\end{array}$ \\
\hline 1 & 8,350 & 10,438 & 12,525 & 14,613 & 16,700 \\
\hline 2 & 11,250 & 14,063 & 16,875 & 19,688 & 22,500 \\
\hline 3 & 14,150 & 17,688 & 21,225 & 24,763 & 28,300 \\
\hline 4 & 17,050 & 21,313 & 25,575 & 29,838 & 34,100 \\
\hline 5 & 19,950 & 24,938 & 29,925 & 34,913 & 39,900 \\
\hline 6 & 22,850 & 28,563 & 34,275 & 39,988 & 45,700 \\
\hline 7 & 25,750 & 32,188 & 38,625 & 45,063 & 51,500 \\
\hline 8 & 28,650 & 35,813 & 42,975 & 50,138 & 57,098 \\
\hline 9 & 31,550 & 39,438 & 47,325 & 55,213 & 58,339 \\
\hline 10 & 34,450 & 43,063 & 51,675 & 59,580 & NA \\
\hline 11 & 37,350 & 46,688 & 56,025 & 60,821 & NA \\
\hline 12 & 40,250 & 50,313 & 60,375 & 62,063 & NA \\
\hline 13 & 43,150 & 53,938 & 64,725 & NA & NA \\
\hline Over 13 & $\begin{array}{l}\text { Add 2,900 for each } \\
\text { additional member }\end{array}$ & $\begin{array}{l}\text { Add 3,625 for each } \\
\text { additional member }\end{array}$ & $\begin{array}{l}\text { Add } 4,350 \text { for each } \\
\text { additional member }\end{array}$ & NA & NA \\
\hline $\begin{array}{l}\text { BENEFIT } \\
\text { LEVEL }\end{array}$ & $\$ 900$ & $\$ 750$ & $\$ 690$ & $\$ 645$ & $\$ 605$ \\
\hline +High Energy* & $\$ 200$ & $\$ 150$ & $\$ 150$ & $\$ 150$ & $\$ 150$ \\
\hline $\begin{array}{l}\text { SUBSIDIZED } \\
\text { HOUSING }\end{array}$ & $\$ 450$ & $\$ 375$ & $\$ 345$ & $\$ 325$ & $\$ 305$ \\
\hline +High Energy* & $\$ 200$ & $\$ 150$ & $\$ 150$ & $\$ 150$ & $\$ 150$ \\
\hline
\end{tabular}

*Plus High Energy usage, if eligible.

High Energy thresholds are: $\quad$ Heating Oil \$900, Natural Gas \$935, Propane \$950, Electricity $\$ 1,190$, Other fuels (wood, coal) $\$ 660$. 


\section{FUEL ASSISTANCE PROGRAM 1997-1998}

\section{FUEL PROGRAM 1997-98 ELIGIBILITY GUIDELINES}

ELIGIBILITY FOR THE ABCD FUEL ASSISTANCE PROGRAM IS BASED ON TOTAL GROSS INCOME (BEFORE TAXES AND DEDUCTIONS) FOR ALL HOUSEHOLD MEMBERS AND VULNERABILITY TO ENERGY COSTS.

\begin{tabular}{|c|c|c|c|c|}
\hline $\begin{array}{c}\text { Number of } \\
\text { Household } \\
\text { Members }\end{array}$ & $\begin{array}{c}100 \% \text { of } \\
\text { Poverty }\end{array}$ & $\begin{array}{c}125 \% \text { of } \\
\text { Poverty }\end{array}$ & $\begin{array}{c}150 \% \text { of } \\
\text { Poverty }\end{array}$ & $\begin{array}{c}175 \% \text { of } \\
\text { Poverty }\end{array}$ \\
\hline 1 & 7,890 & 9,863 & 11,835 & 13,808 \\
2 & 10,610 & 13,263 & 15,915 & 18,568 \\
3 & 13,330 & 16,663 & 19,995 & - \\
4 & 16,050 & 20,063 & 24,075 & - \\
\hline 5 & 18,770 & 23,463 & 28,155 & - \\
6 & 21,490 & 26,863 & 32,235 & - \\
7 & 24,210 & 30,263 & 36,315 & - \\
8 & 26,930 & 33,663 & 40,395 & - \\
\hline Over 8 & $\begin{array}{l}\text { Add } 2,720 \\
\text { for each } \\
\text { additional } \\
\text { member }\end{array}$ & $\begin{array}{l}\text { Add } 3,400 \\
\text { for each } \\
\text { additional } \\
\text { member }\end{array}$ & $\begin{array}{l}\text { Add } 4,080 \\
\text { for each } \\
\text { additional } \\
\text { member }\end{array}$ & \\
\hline $\begin{array}{l}\text { BENEFIT } \\
\text { LIMIT }\end{array}$ & $\$ 380$ & $\$ 340$ & $\$ 205$ & $\$ 120$ \\
\hline $\begin{array}{l}\text { SUBSIDIZED } \\
\text { HOUSING }\end{array}$ & $\$ 125$ & $\$ 115$ & $\$ 70$ & $\$ 40$ \\
\hline
\end{tabular}




\section{FUEL ASSISTANCE PROGRAM 1998-1999}

FUEL PROGRAM 1998-99 ELIGIBILITY GUIDELINES

ELIGIBILITY FOR THE ABCD FUEL ASSISTANCE PROGRAM IS BASED ON TOTAL GROSS INCOME (BEFORE TAXES AND DEDUCTIONS) FOR ALL HOUSEHOLD MEMBERS AND VULNERABILITY TO ENERGY COSTS.

\begin{tabular}{|c|c|c|c|c|}
\hline $\begin{array}{c}\text { Number of } \\
\text { Household } \\
\text { Members }\end{array}$ & $\begin{array}{c}100 \% \text { of } \\
\text { Poverty }\end{array}$ & $\begin{array}{c}125 \% \text { of } \\
\text { Poverty }\end{array}$ & $\begin{array}{c}150 \% \text { of } \\
\text { Poverty }\end{array}$ & $\begin{array}{c}175 \% \text { of } \\
\text { Poverty }\end{array}$ \\
\hline 1 & 8,050 & 10,063 & 12,075 & 14,088 \\
2 & 10,850 & 13,563 & 16,275 & 18,988 \\
3 & 13,650 & 17,063 & 20,475 & - \\
4 & 16,450 & 20,563 & 24,675 & - \\
\hline 5 & 19,250 & 24,063 & 28,875 & - \\
6 & 22,050 & 27,563 & 33,075 & - \\
7 & 24,850 & 31,063 & 37,275 & - \\
8 & 27,650 & 34,563 & 41,475 & - \\
\hline Over 8 & $\begin{array}{l}\text { Add } 2,800 \text { for } \\
\text { each additional }\end{array}$ & $\begin{array}{l}\text { Add } 3,500 \text { for } \\
\text { each additional } \\
\text { member }\end{array}$ & $\begin{array}{l}\text { Add } 4,200 \text { for } \\
\text { each additional } \\
\text { member }\end{array}$ & - \\
\hline $\begin{array}{l}\text { BENEFIT } \\
\text { LIMIT }\end{array}$ & $\$ 440$ & $\$ 395$ & $\$ 235$ & $\$ 120$ \\
\hline $\begin{array}{l}\text { SUBSIDIZED } \\
\text { HOUSING }\end{array}$ & $\$ 145$ & $\$ 135$ & $\$ 20$ & $\$ 10$ \\
\hline
\end{tabular}

In addition to the above base benefits, clients may qualify for an additional $\$ 150.00$ (nonsubsidized housing) or $\$ 50.00$ (for those in subsidized housing). To qualify, a household fuel costs for the past 12 months must exceed a certain threshold according to fuel source. Call ABCD at 357-8012 for more information. 
FUEL ASSISTANCE PROGRAM 1999-2000

\section{REVISED ELIGIBILITY GUIDELINES As of 4/11/2000 per J. Hays, DHCD}

\section{MASSACHUSETTS FY2000 LIHEAP INCOME ELIGIBILITY CHART}

ABCD FUEL ASSISTANCE PROGRAM ELIGIBILITY IS BASED ON TOTAL GROSS INCOME (BEFORE TAXES \& DEDUCTIONS) FOR ALL HOUSEHOLD MEMBERS AND VULNERABILITY TO ENERGY COSTS.

***CALL 357-6012 FOR ABCD FUEL ASSISTANCE PROGRAM $* * *$ (Rev. \#4)

\begin{tabular}{|c|c|c|c|c|c|c|}
\hline $\begin{array}{l}\text { Number in } \\
\text { Household }\end{array}$ & $\begin{array}{l}100 \% \text { of } \\
\text { Poverty }\end{array}$ & $\begin{array}{l}125 \% \text { of } \\
\text { Poverty }\end{array}$ & $\begin{array}{l}150 \% \text { of } \\
\text { Poverty }\end{array}$ & $\begin{array}{l}175 \% \text { of } \\
\text { Poverty }\end{array}$ & $\begin{array}{l}200 \% \text { of } \\
\text { Poverty }\end{array}$ & $\begin{array}{l}\text { 60\% STATE } \\
\text { Median }\end{array}$ \\
\hline 1 & 8,240 & 10,300 & 12,360 & 14,420 & 16,480 & 20,284 \\
\hline 2 & 11,060 & 13,825 & 16,590 & 19,355 & 22,120 & 26,525 \\
\hline 3 & 13,880 & 17,350 & 20,820 & 24,290 & 27,760 & 32,756 \\
\hline 4 & 16,700 & 20,875 & 25,050 & 29,225 & 33,400 & 39,007 \\
\hline 5 & 19,520 & 24,400 & 29,280 & 34,160 & 39,040 & 45,248 \\
\hline 6 & 22,340 & 27,925 & 33,510 & 39,095 & 44,680 & 51,490 \\
\hline 7 & 25,160 & 31,450 & 37,740 & 44,030 & 50,320 & 53,035 \\
\hline 8 & 27,980 & 34,975 & 41,970 & 48,965 & 55,960 & 54,580 \\
\hline Over 8 & $\begin{array}{l}\text { Add } 2,820 \\
\text { for each } \\
\text { additional } \\
\text { member }\end{array}$ & $\begin{array}{l}\text { Add } 3,525 \\
\text { for each } \\
\text { additional } \\
\text { member }\end{array}$ & $\begin{array}{l}\text { Add } 4,230 \\
\text { for each } \\
\text { additional } \\
\text { member }\end{array}$ & $\begin{array}{l}\text { Add } 4,935 \\
\text { for each } \\
\text { additional } \\
\text { member }\end{array}$ & $\begin{array}{l}\text { Add } 5,640 \\
\text { for each } \\
\text { additional } \\
\text { member }\end{array}$ & $\begin{array}{l}\text { Add } 3 \% \\
\text { for each } \\
\text { additional } \\
\text { member }\end{array}$ \\
\hline $\begin{array}{l}\text { OIL/PROPANE } \\
\text { Deliverable Fuels }\end{array}$ & $\$ 960$ & $\$ 895$ & $\$ 655$ & $\$ 500$ & $\$ 500$ & $\$ 300$ \\
\hline SUBSIDIZED Hsg & $\$ 540$ & $\$ 525$ & $\$ 440$ & $\$ 380$ & $\$ 380$ & $\$ 300$ \\
\hline $\begin{array}{l}\text { GAS/ELECTRIC } \\
\text { Nondeliverable Fuels }\end{array}$ & $\$ 545$ & $\$ 495$ & $\$ 310$ & $\$ 180$ & $\$ 150$ & NA \\
\hline SUBSIDIZED Hsg & $\$ 185$ & $\$ 75$ & $\$ 110$ & $\$ 65$ & $\$ 65$ & NA \\
\hline
\end{tabular}


ORNL/CON-486

\section{INTERNAL DISTRIBUTION}

1. L. G. Berry

2. M. A. Brown

3. T. R. Curlee

4. J. E. Christian

5. W. G. Craddick

6-30. M. T. Eady

31. J. F. Eisenberg

32. E. C. Fox

33. M. B. Gettings

34. S. G. Hildebrand
35. D. W. Jones

36. R. M. Lee

37. M. Martin

38. M. Schweitzer

39. R. L. Schmoyer

40. R. B. Shelton

41. B. E. Tonn

42-44. ESD Library

45. ORNL Central Research Library

46. ORNL Laboratory Records-RC

\section{EXTERNAL DISTRIBUTION}

47. Mr. Eric Beaton, U.S. DOE Boston Regional Office, Weatherization Program Manager, JFK Federal Building, Room 675, Boston, MA 02203-0002

48. Beth M. Cahall, U.S. DOE Philadelphia Regional Office, Weatherization Program Manager, 1880 John F. Kennedy Boulevard, Suite 501, Philadelphia, PA 19103-7483

49. Clarence Carter, Director, Department of Health and Human Services, Administration for Children and Families, Office of Community Services, $5^{\text {th }}$ Floor East, Aerospace Building, 370 L'Enfant Promenade, S.W., Washington, DC 20447

50. James J. Childs, U.S. DOE, EE-42, Room 5E-066, Office of Technology Assistance, 1000 Independence Avenue, S.W., Washington, DC 20585

51. Rob DeSoto, U.S. DOE Golden Regional Office, Weatherization Program Manager, 1617 Cole Boulevard, Golden, CO 80401

52. Jean M. Diggs, U.S. DOE, EE-42, Room 5E-080, Office of Technology Assistance, 1000 Independence Avenue, S.W., Washington, DC 20585

53. Thomas E. Drabek, Professor, Department of Sociology, University of Denver, Denver, CO 80208-0209

54. Denis J. Feck, U.S. DOE, EE-42, Room 5E-098, Office of Technology Assistance, 1000 Independence Avenue, S.W., Washington, DC 20585

55. Carole Gates, U.S. DOE Seattle Regional Office, Weatherization Program Manager, 800 Fifth Avenue, Suite 3950, Seattle, WA 98104

56. Elliott Jacobsen, Director of Energy Programs, Action, Inc., 4 Washington Street, Gloucester, MA 01930

57. Mike Kessler, Family Independence Agency, 235 S. Grand Avenue, Lansing, MI 48909

58. Leon Litow, Department of Health and Human Services, Administration for Children and Families, Office of Community Services, Division of Energy Assistance, 5th Floor West, Aerospace Building, 370 L’Enfant Promenade, S.W., Washington, DC 20447 
59-68. Gail N. McKinley, U.S. DOE, EE-42, Room 5E-080, Office of Technology Assistance, 1000 Independence Avenue, S.W., Washington, DC 20585

69. Victoria Mroczek, Chief, Office of Community Services, Ohio Department of Development, 77 South High Street, $25^{\text {th }}$ Floor, Columbus, OH 43216-1001

70. Michael Peterson, U.S. DOE Chicago Regional Office, Weatherization Program Manager, One South Wacker Drive, Suite 2380, Chicago, IL 60606

71. Gregory M. Reamy, U.S. DOE, EE-42, Room 5E-066, Office of Technology Assistance, 1000 Independence Avenue, S.W., Washington, DC 20585

72. P. Richard Rittelmann, FAIA, Executive Vice President, Burt Hill Kosar Rittelmann Associates, 400 Morgan Center, Butler, PA 16001-5977

73. Bernadette Ruffin, U.S. DOE Atlanta Regional Office, Weatherization Program Manager, 730 Peachtree Street, N.E., Suite 876, Atlanta, GA 30308

74. Richard Saul, Director, Department of Health and Human Services, Administration for Children and Families, Office of Community Services, Community Demonstration Programs Division, 5th Floor West, Aerospace Building, 370 L'Enfant Promenade, S.W., Washington, DC 20447

75. Sarah Wagner, University of Tennessee, Knoxville, TN

76. Sara Ward, Chief, Office of Energy Efficiency, Ohio Department of Development, 77 South High Street, $26^{\text {th }}$ Floor, Columbus, OH 43216-1001

77-79. John Wells, ABCD, 178 Tremont Street, Boston, MA 02111 